\title{
Skematiserende verbalpræfikser i dansk og lignende konstruktioner i spansk
}

\author{
Johan Pedersen
}

\begin{abstract}
The article examines transitive prefix constructions in Danish. It argues that the prefixes $b e-/$ for- are markers of a productive lexemeindependent argument structure construction that can also be found in other Germanic languages. In contrast, comparable Spanish affixations are not lexeme-independent transitive markers, and they are only productive as morphological constructions of verbal derivation. The article hypothesizes that in sentence structure, the role of productive schematic patterns (generalized from usage) and verbal (lexical) information, respectively, are language type specific.
\end{abstract}

\section{Nøgleord}

verbalpræfiks, argumentstruktur, konstruktioner, produktivitet

\section{Indledning}

Dette studie undersøger en bestemt type transitive præfikskonstruktioner i dansk ([SUBJEKT - (præfiks+basisleksem+fleksiv) $)_{\mathrm{V}}$ - OBJEKT]) og diskuterer kort, til sammenligning, analysen af lignende konstruktioner i spansk. Jeg vil særligt fokusere på den rolle verbets komponenter spiller for betydningen i disse konstruktioner. Be- er eksempelvis et verbalpræfiks der ud fra et basisverbum, et substantiv eller et adjektiv, danner et afledt verbum og nogle karakteristiske transitive konstruktioner og betydninger.

(1) Peter snakker med den ældre dame. (intransitiv)

(2) Peter besnakker den ældre dame. transitiv) 'Peter påvirker den ældre dame med sin manipulerende snak' 
(3) Kunstneren besjæler sit værk.

'Kunstneren giver sit værk sjæl'

(transitivitet skabes)

Normalt siger man at præfikser, i modsætning til suffikser, ikke ændrer basisordets ordklasse:

"Præfiks er en orddannende forstavelse. I modsætning til suffikser ændrer præfikser ikke de præfigerede ords ordklasse, men modificerer deres betydningsindhold." (Opslag i Den Store Danske).

I (2) ændrer verbalpræfikset be-således den intransitive aktivitetsbetydning til en transitiv betydning. Eksempel (3) viser imidlertid at en verbal præfigering også kan implicere et ordklasseskift; her fra substantiv (sjel) til verbum (besjele). Eksemplerne viser også at præfigeringen ofte har betydning for valensstrukturen. I (2) kan den transitive betydning ikke afledes af valensstrukturen i basisleksemet at snakke (sml. (1)), og i (3) er præfigeringen ikke blot valensændrende, men valensskabende. Det ses af at den transitive betydning ' $\mathrm{X}$ forsyner $\mathrm{Y}$ med Z' vanskeligt kan siges at være en konsekvens af en valensstruktur i substantivet sjal. Præfikset er også valensskabende når det præfigerer et adjektiv og derved skaber en verbal prædikation med transitiv (resultativ) valensstruktur som i Peter beroliger sin kereste.

I spansk er verbalafledninger generelt meget produktive, og navnlig konstruktioner med valensskabende verbalpræfiks (jf. (4)) er direkte sammenlignelige med de danske konstruktioner, ikke kun med hensyn til form, men også hvis man ser på argumentstrukturen og de mulige betydninger. Dette er bemærkelsesværdigt hvis man tænker på at disse såkaldte applikative konstruktioner med $b$-præfiks - med henvisning til karakteristiske applikative konstruktioner i andre sprogfamilier - behandles som et specifikt germansk (og ikke romansk) fænomen i litteraturen. Dette er på den anden side naturligt når præfiksets etymologi og den generelle germanske afstamning tages i betragtning.

$$
\begin{aligned}
& \text { La arena em-polv-aba los caminos y las casas. } \\
& \text { Sandet i-støv-datid vejene og husene } \\
& \text { 'Sandet dækkede vejene og huset med sand' }
\end{aligned}
$$

I eksempel (4) er basisleksemet substantivet polvo 'støv', og kernebetydningen er 'X dække Y med Z (SUBS)'. Vi ser en klar parallel til den danske be-konstruktion i (3). Men til forskel fra den danske konstruktion er kernebetydningen transparent og kan udledes af det afledte verbums elementer (em-polvo-ar = 'i støv-proces'). 
I artiklen vil jeg diskutere analysen af de danske be-konstruktioner, som jeg som noget helt centralt også applicerer på lignende konstruktioner med verbalpræfikset for-. Jeg vil derefter vise at disse konstruktioner er produktive i dansk (og ikke kun er indlån fra tysk), og til sidst vil jeg kort diskutere sammenligningen med spansk.

\section{Baggrund}

Petré \& Cuyckens (2008) analyserer den historiske udvikling og grammatikalisering af det engelske verbalpræfiks be-, der i kombination med et basisleksem resulterer i en række karakteristiske transitive konstruktioner. Analysen er baseret på Michaelis \& Ruppenhofers (2001) tidligere konstruktionistiske analyse af det tyske applikative be-præfiks, som er eksemplificeret i (5).

$\begin{array}{ll}\text { Sie bewanderte den Schwarzwald. } & \text { (Michaelis \& Ruppenhofer } \\ \text { 'Hun vandrede gennem Schwarzwald' 2001: 2) }\end{array}$

I (5) skaber be-præfikset en transitiv bevægelseskonstruktion ud fra det intransitive simpleksverbum wanderte 'vandrede'. Andre germanske sprog har lignende konstruktioner. I et bredere sprogtypologisk perspektiv, og med henvisning til Haspelmath (2011), Kulikov (2011) og Kittilä (2011), definerer Nielsen (2018) valensændrende affikser som affikser der påvirker et verbums argumentstruktur, enten ved at tilføje eller fjerne et direkte argument, eller ved at ændre typen af participanter som kan udtrykkes ved et direkte argument. ${ }^{1}$ Fx tilføjer applikativer en ikke-agent som et direkte argument. I Michaelis \& Ruppenhofers analyse er det imidlertid en central pointe at den applikative $b$-konstruktion ikke blot tilføjer et argument (valence-augmentation), men også kan være valensskabende (valence-creation), fx i konstruktioner hvor basisleksemet er et substantiv (og ikke et verbum) som i (6), hvor basisleksemet er Haar 'hår'.

(6) Es mag ja lustig sein, twei hartgekochte Eier wie Clownsköpfe mit angekeimten Sojabohnen zu Behaaren, ... (Michaelis \& Ruppenhofer 2001: 5).

'Ok, det kunne være sjovt at be-håre to hårdkogte æg som klovnehoveder med spirende sojabønner'

1 Et direkte argument er et subjekt, direkte objekt eller indirekte objekt. 
Det er også centralt i Michaelis \& Ruppenhofer (2001) og Petré \& Cuyckens' (2008) konstruktionistiske analyser at præfiksets rolle ses som analog med den betydningsskabende rolle den diagrammatiske argumentstrukturkonstruktion har i en "almindelig" ikke-præfigeret transitivkonstruktion (SUBJ V OBJ). For det første fordi præfikset, som $\mathrm{fx}$ be-, er uadskilleligt fra verbaldannelsen, dvs. det forekommer ikke uafhængigt af det præfigerede ord. Sætningens diagrammatiske argumentstrukturkonstruktion, der bidrager med sin egen transitive betydning (fx [SUBJ V OBJ]/'X TRANS Y'), forekommer heller ikke i sprogbrugen uafhængigt af sætningens konstituenter (verbet og nominalsyntagmer). For det andet kan vi konstatere at be-præfikset, som en naturlig følge af det lige nævnte, er tryksvagt (i modsætning til præfikser i sammensatte verbaler, fx opstille), ligesom den abstrakte diagrammatiske argumentstrukturkonstruktion naturligt nok heller ikke kan være belagt med tryk. For det tredje er der en analogi i og med at be-præfikset og den diagrammatiske argumentstrukturkonstruktion begge har valensskemaegenskaber (dvs. de er argumentselekterende). Det betyder at selvom de ikke kan adskilles fra sætningens verbale konstituent (se ovenfor), er de begge argumentselekterende uafhængigt af verballeksemet (sml. Goldberg 1995; Booji 2010). Vi kan således tale om en morfologisk skematisering af sætningen når et tryksvagt verbalpræfiks som be-, ud over sin obligatoriske rolle som uadskillelig verbal derivativ markør, bestemmer en argumentselekterende valensstruktur i sætningen - uafhængigt af verbets basisleksem.

Som en direkte konsekvens af at være skematiserende og valensskabende, bestemmer be-konstruktionen en transitiv argumentstruktur med en karakteristisk semantisk struktur der ikke kan tilskrives basisleksemet. Den germanske be-konstruktions forskellige betydninger er, ifølge Michaelis \& Ruppenhofer (2001), prototypebaseret, med betydningselementet coverage som kerneelement. De følgende hovedkategorier er således på forskellig vis relateret til denne prototype:

Coverage (fx 'dække', 'mætte', 'fuldende', 'gå igennem', 'konsumere'...) Affectedness ( $\mathrm{fx}$ 'rette handling mod', 'forstærke', 'gentage' ...) Transfer (fx 'overføre', 'udstyre/forsyne med' ...)

$B e$-'s betydning stammer, ifølge Michaelis \& Ruppenhofer (2001), fra den leksikalske betydning 'around' der er forbundet med præpositionen $b i$, der historisk går forud for $b e$.

"The most plausible source for the semantics of coverage associated with the be-pattern is the 'around' schema associated with the 
historic precursor of be, the preposition bi. The modern English and German prepositions meaning 'around' - around and um/herum, respectively - are ambiguous between a sense of 'surrounding an enclosed place' and 'being distributed over a surface area"' (Michaelis \& Ruppenhofer 2001: 64).

Petré \& Cuyckens (2008) udfolder denne analyse med henblik på be-konstruktionens udvikling i Old English, Middle English og Present-Day English. De betragter en 'surrounding' be-konstruktion som den oprindelige prototype, hvorfra de forskellige grammatikaliserede betydninger har udviklet sig; se ovenfor. 'Transfer'-konstruktionen, som de betegner furnishing, er som den seneste variant baseret på et substantiv som basisleksem (sml. (6)). Bekonstruktionen er dog generelt i tilbagegang i engelsk selvom nydannelser af furnishing-typen stadig kan observeres (Petré \& Cuyckens 2008).

\section{Skematiserende verbalpræfikser $i$ dansk}

Med inddragelse af diskussionen i afsnit 2 vil jeg definere verbalpræfikset i dansk snævert, således at det primært omfatter be- og for-, og dermed afgrænse det i forhold til andre præfigerende morfemer:

1) Verbalpræfikset er uadskilleligt fra verbaldannelsen, og har således ikke derudover (med samme betydning) en selvstændig anvendelse.

2) Verbalpræfikset er tryksvagt.

3) Verbalpræfikset kan være valensskabende.

Ifølge Aage Hansen (1967) er der tre verbalpræfikser i dansk, be-, for- og mis-, hvoraf be- og for-fremstår som de vigtigste. Hansen henviser i øvrigt til ODS. Mis- med negerende betydning er også uadskilleligt fra verbaldannelsen (jf. 1), men falder uden for min afgrænsning af verbalpræfikset da det ikke kan være valensskabende (jf. 3) og er trykstærkt (jf. 2), fx i Peter misinformerer, og i den forstand opfører sig som foranstillede præpositioner og adverbier i sammensætninger (sml. bortskaffe). ${ }^{2}$ Ifølge Hansen (1967:

2 Hansen (1967) omtaler også brugen af $u$ - i participialdannelser uden tilsvarende finit verbum; fx $\boldsymbol{u}$ passende eller $\boldsymbol{u}$ vidende. Det falder imidlertid uden for min definition af verbalpræfikset da det er trykstærkt, hvormed det markeres at det bidrager med en selvstændig, transparent (negerende) betydningskomponent i det sammensatte verbal. Hansen (1967) skelner i øvrigt mellem egentlig 'præfigering', fx betitle, og 'sammensætning', fx gennemtvinge, i verbaldannelsen. 
181) kan be-i samtiden bruges til nydannelser, især af den spøgende slags og oftest i perfektum participiumsformen, som i Verelserne er ... svagt beteppede. Andre eksempler er: betitlede, bespottede, bemaabet, bedigtede, bemalede, bejublede, bekitlede, behjelmede, beneje, bejae, bestalde (en hest) ... Basisleksemet er i disse eksempler substantiv eller verbum, men andetsteds har han også eksempler med adjektiv som basisleksem: begunstige, bemyndige (Hansen 1967: 178). Om for-skriver Hansen (1967: 181):

\begin{abstract}
"Til nydannelser bruges det især hvor man vil betegne en forandring, forvandling til det der angives af det ord (substantiv eller adjektiv) der er kernen i afledningen. Ligesom ved be-afledningen er nydannelser her ved for- også nu for det meste spøgende eller nedsættende, og afledningen er hyppigst brugt i perfektparticipiet .... en forpimpet champagnegrosserer." Eksemplet er fra Nordiske Sprogproblemer (1957: 52).
\end{abstract}

Ifølge Durst-Andersen \& Herslund (1996: 90-92) er be-præfigeringen den eneste derivative verbaldannelse i dansk der klart er morfologisk af natur (dvs. uadskilleligt fra verbaldannelsen [min læsning]). Præfiksets funktion er, ifølge forfatterne, at være valensændrende og transitiverende:

"The very productive prefix be-, essentially a transitivising morpheme, resembles in many respects the so-called applicative morphemes of African languages. Like applicative morphemes, the prefix enables the stem, canonically, to select as an object what would otherwise be realized as a locative complement or adjunct, but other possibilities exist as well” (Durst-Andersen \& Herslund 1996: 90-91).

Forfatterne nævner at verbet kan være afledt af et substantiv, men ikke at basisleksemet også kan være et adjektiv, og kommer i øvrigt ikke nærmere ind på præfiksets rolle i disse tilfælde, som vanskeligt kan rubriceres under den valensændrende funktion. Endelig behandler de ikke præfikset for-. For- ser på mange måder ud til at fungere ligesom be-, men til forskel fra be- er for- hyppigt forekommende med adjektiv som basisleksem. ${ }^{3}$

Både be- og for- er uadskillelige fra verbaldannelsen, tryksvage og kan være valensskabende. Den valensskabende evne indebærer, som vi skal se

3 For har i øvrigt en række andre veldefinerede anvendelser og betydninger, som ikke kan sidestilles med dets anvendelse som præfiks. Sml. fx for dum eller synge for, men forsegle $=*$ for segl, *segle for. 
i næste afsnit, at der tilføjes et transitivt valensskema, og at dette hverken kan udledes af basisleksemet eller blot er en ændring af leksikalsk bestemt valensstruktur. Dvs. præfikset opererer ikke på basisleksemet. Det er derfor ikke tilstrækkeligt at tale om en promovering af et sætningsargument eller en verbalvalensforøgelse. Vi kan til gengæld tale om en morfologisk skematisering af sætningen når et præfiks som be- eller for-, ud over sin rolle som verbalt derivativ, tilføjer en transitiv valensstruktur og dermed skematiserer sætningsbetydningen uafhængigt af basisleksemet - som evt. kan være et substantiv. Med andre ord kan det betydningsbærende transitive skema i sætningen ikke forankres leksikalsk. Præfiksets transitive skematisering er således en morfologisk markeret analog udgave af den diagrammatiske argumentstrukturkonstruktions uafhængige betydningsbidrag i the crew manned the boats ([SUBJ V OBJ] / ' $\mathrm{X}, \mathrm{Y}$ i transitiv relation'). Sml. besetningen bemandede bådene.

\subsection{Be- og for-konstruktioner-anvendelser og betydnings- kategorier}

De fleste danske verbalpræfikskonstruktioner stammer fra tilsvarende tyske konstruktioner (se afsnit 2), men moderne dansk ser også ud til at have en generaliseret produktiv verbalpræfikskonstruktion (se afsnit 3.1.1). Hvis vi ser bort fra tilfælde med egentlig leksikalisering hvor basisleksemet ikke har en selvstændig betydning i det afledte verbum, eller hvor det afledte verbum får en helt ny betydning; fx begynde, bedrøve, bebrejde, besøge, forfatte, forlade, forsage, eller forkynde, kan både be- og for-konstruktionerne i dansk beskrives med de samme betydningskategorier som har været hovedelementerne $\mathrm{i}$ analyser af den tyske og den engelske be-konstruktion (se afsnit 2).

Som vi så i afsnit 2, anser Michaelis \& Ruppenhofer (2001) betydningselementet coverage for at være kerneelementet i be-konstruktionens betydning. De argumenterer for at man kun kan forklare $b$-konstruktionen ved at se på hvordan dens betydning og anvendelse relaterer sig til den historiske udvikling af $b i$ - 'around' og forandrer sig (se citat ovenfor). Det synes umiddelbart at være en plausibel tilgang til analysen af be-konstruktionen. Det er dog påfaldende at præfikset for-, som må antages at have en noget anden betydningsstruktur og etymologi (fra tysk vor-/ver-) i store træk giver de samme betydningsmuligheder som be-præfikset. Det indikerer at analysen af $b e$-konstruktionens betydning, i modsætning til argumentationen i Michaelis \& Ruppenhofer (2001), ikke behøver være snævert forbundet med den historiske udvikling af præfikset be- og dets kernebetydning; og mht. dansk, ikke bør være det. I dansk er der måske snarere tale om en mere generel 
skematiserende konstruktionsdannelse med be- eller for-. Distributionen på de forskellige anvendelser er anderledes og komplementær for for-i forhold til be-, hvilket giver god mening ud fra et funktionelt synspunkt. Selvom de to præfikser har de samme betydningsmuligheder, forekommer det samme basisleksem sjældent med både be- og for- i samme betydning (det kan dog godt forekomme, se fx (12)-(13) nedenfor). For eksempel kan man forgylde nogen (via 'guld-transfer') og man kan besmykke nogen (via 'smykke-transfer'), men man kan ikke *begylde nogen, og man kan ikke *forsmykke nogen.

Hvis vi antager at præfikset generelt tilføjer et transitivt valensskema i forbindelse med verbaldannelsen ('X TRANS Y'), jf. afsnit 3, og dermed markerer den transitive relation, vil basisleksemet enten specificere den transitive relation (fx ved at specificere 'måde' eller 'transfer/middel'), eller angive resultatet af den transitive relation. ${ }^{4}$

A) Transitiv relation med mådesspecifikation. Præfikset markerer transitivitet i verbum med (in)transitivt basisverbum: Den transitive effekt fremhæves og specificeres i basisverbet. I eksempel (7), (8) og (9) fremhæves den transitive effekt og specificeres i basisverbet: 'Han har en ledende effekt på virksomheden ved at styre den', 'han har en effekt på vildtet ved at jage det', og 'han retter effektfuldt opmærksomheden mod en matematisk sammenhæng ved at vise den.' I visse tilfælde resulterer præfigeringen i en ganske lille betydningsforskel, som fx i (10).

(7) Han bestyrer en virksomhed.

(8) Han forjager vildtet.

(9) Han beviser en matematisk sammenhæng.

(10) Han benægter ethvert kendskab til sagen.

I (1 1) påvirker manden den ældre dame med sin manipulerende snak, og i (12) og (13) gør subjektet noget ved træet ved at arbejde med det.

(11) Manden besnakkede den ældre dame.

'Manden påvirkede den ældre dame med sin manipulerende snak'

4 Præfikset kan også i visse tilfælde danne adjektiv med verbum som basisleksem, fx forblæst, fordrukken eller belæst. 
(12) Han bearbejdede træet.

(13) Han forarbejdede træet.

I (14) må subjektet ikke komme i kontakt med græsset ved at træde på det, og i (15) gør Peter noget ved spørgsmålene ved at svare på dem.

(14) Man må ikke betræde græsset.

(15) Peter besvarer spørgsmålene.

Følgende verber er andre eksempler hvor basisverbet specificerer den fremhævede transitive relations måde: ${ }^{5}$ bekcmpe, betvivle, besejle, beklappe, belure, belyse, befamle, bekysse, bese, begrine, beflyve, bestige, bedryppe, besove, beskide, fordømme, forkrolle, forbande, forpine.

B) Transitiv relation med 'transfer-/middelspecifikation'. Præfikset er valensskabende i transitivt verbum med substantiv som basisleksem der specificerer 'transfer'-/'middel'-betydningen (overførsel af substantivisk størrelse).

(16) Bien bestøvede blomsterne.

(17) Nasa bemander rumskibet.

I (16) og (17) påvirker subjektet blomsterne/rumskibet ved at der overføres henholdsvis støv og mand. I (18) og (19) gør subjektet noget ved objektet ved at påføre det henholdsvis en byrde og et segl.

(18) Det ekstra arbejde bebyrder de ansatte.

(19) Han forseglede brevet.

5 For- kan også fremhæve/forstærke en intransitiv eller refleksiv situation, eller skabe intransitiv valens, med betydningen tilstandsændring, intensivering, grænseoverskridende handling e.l., fx forsvinde, forblode, forhaste sig, fordampe, forstene. 
Følgende er andre eksempler på en 'transfer-/middelspecifikation', hvor basissubstantivet specificerer den transitive relation som en transferbetydning: besegle, befolke, behuse, belejre, behatte, benåde, beramme, benytte, betitle, bemidle, besko, besmykke, beperle, beruse, forulempe, fornagle, forpagte, forgylde, forsolve, forzinke, forkrome, fornikle, fortinne, forhude, forkkalle, forsåle, forskanse (sig), forgifte, forpeste, forurette, forpligte, forrente.

C) Transitiv relation med resultativ betydning. Præfikset er verbalvalensskabende i verber med adjektiv eller substantiv som basisleksem og resultativ transitiv betydning. Den resultative variant er yderst hyppig med for-, hvorimod den er relativt sjældent forekommende med be-. Den resultative be-variant kan også observeres i engelsk (Petré \& Cuyckens 2008). I (20) og (21) har subjektet en indvirkning på objektet, som resulterer i at objektet gennemgår en forandring til det der udtrykkes i basisleksemet.

(20) Peter forenklede processen. [SUBJ $\left.(\text { for-ADJ })_{\mathrm{V}} \mathrm{OBJ}\right] /$ ' $\mathrm{X}$ caused $\mathrm{Y}$ to be $\mathrm{Z}_{\mathrm{ADJ}}$ '

(21) Moderen beroligede datteren.

[SUBJ $\left.(b e-\mathrm{ADJ})_{\mathrm{V}} \mathrm{OBJ}\right]$ / ' $\mathrm{X}$ caused $\mathrm{Y}$ to be $\mathrm{Z}_{\mathrm{ADJ}}$ '

Andre eksempler på den resultative variant er: forny, forstorre, forklare, forarme, forbedre, fordanske, forvarre, forkrøble, forhekse, forgrimme, forringe, forruste, fortravle, forhaje, fordyre, forfine, foradle, forskonne, forynge, forgrove, forrå, forurene, fornedre, forstarke, forkorte, forlange, fortykke, fortynde, forsnaure, fordumme, forstumme, fordunkle, formorke, forandre, fordybe (sig), forenkle, forsimple, forevige, forfalske, forfladige, forklejne, forflygtige, forfriske, forfardige, forlige, formilde, forsøde, forsure, forurolige, fortatte, forivre (sig), forsikre, forvisse, formulde, forstove, forgude, forpligtige, forsmå, bemyndige, besvangre, berige, berigtige.

Vi kan sammenfattende konstatere at de danske verbalpræfikser be- og for- navnlig optræder i tre konstruktionsvarianter, der ser ud til at være produktive i nutidigt dansk: A) 'mådesspecifikation af den transitive relation', B) 'transfer-/middelspecifikation af den transitive relation' og C) 'resultativ transitiv relation'. Varianterne kan sammenfattes i følgende formalisering af verbalpræfikskonstruktionen, hvor specifikation af 'måde' (A) vs. 'transfer' /'middel' (B) er slået sammen til SPEC:

$\left[\mathrm{SUBJ}\left(\text { be/for }_{\mathrm{i}}-\mathrm{LEX}-\mathrm{F}\right)_{\mathrm{V}} \mathrm{OBJ}\right] /$ '(X TRANS Y $)_{\mathrm{i}}+(\mathrm{SPEC} / \mathrm{RESULT})_{\mathrm{LEX}}$ ' 
Jeg vil i det næste afsnit vise med en række eksempler at der sker nydannelser med begge præfikser og med alle tre konstruktionsvarianter. En del af nydannelserne sker som participium perfektumformer af verbet, som også bemærket i Hansen (1967), og er et mønster man også har observeret i engelsk (Petré \& Cuyckens 2008), men der er også mange eksempler på nydannelser med finitte verbalformer.

\subsubsection{Nydannelser}

'Mådesspecifikation':

Herlig fest... min far på 78 med de dårlige knæ bedansede alle damerne (https://jyllands-posten.dk/debat/kronik/ECE10449825/ naar-boern-ikke-bare-kommer/. Lok. 14/11/21). En retarderet mandsling valgte at bedytte mig hårdt bagfra, faktisk så hårdt at jeg faldt af cyklen! (https://www.hardwareonline.dk/traad. aspx?fid=23\&tid=817244. Lok. 14/11/21). Foragt forkrøller ansigtet og lukker næseborene for at holde uønskede lugte ude. (https:// www.mm.dk/pdffiles/638df-22199707.pdf. Lok. 14/11/21).

Eksempler på andre nydannelser: bebombe, becykle, besmile, befiske, beprutte, forklowne, fordukke, fordigte sig.

'Transferspecifikation':

Vi skulle i frihavnen og se hvad der nu kom hjem.... Første bil til at behjule ... dansk grund var den store Buick. Nu med sort kaleche... (http://www.carnut.dk/carnut-gar-tilbage-i-tiden-del-21. Lok. 14/11/21). På grund af arrangementet af lysdioder i forskellige højder, forkranser denne krans perfekt enhver facade ( $\underline{\text { https:// }}$ da.rowladyland.com/dom / 19790-ulichnaya-girlyanda-bahroma. html. Lok. 14/11/21). DFDS inviterer endnu engang til julefest hvor der ikke er langt fra bordet til køjen - selv de mest forsnapsede kan være med her (https:/ /uuqp7799.com/julefrokost-arrangementkobenhavn-online.html. Lok. 14/11/21).

Eksempler på andre nydannelser: betjere, bebukset, beslipset, besovsede, beflasket, behestede, besprittede, bemaskede, forpinde, forgrannede, forgarnede, forhashede, forlortede, forsovsede, forsexede. 
'Resultativ':

TV2 klipper så tilbage i studiet, hvor de har hevet folk ind som kan bekloge os andre... (https://rolflarsen.wordpress.com/2010/02/20/ all-round-eksperten. 14/11/21). Jeg undskylder for at forsyge jeres lille hyggeaften, sagde han (https://truyen4u.net/don-t-know-whyhvem-vandt-730117236.html. 14/11/21). Realdania vil forgrønne almene renoveringer (http:// www.dagensbyggeri.dk/artikel/112361realdania-vil-forgronne-almene-renoveringer. 14/11/21).

Eksempler på andre nydannelser: forfranske, forsjove, fortrolde, foroste, fornare, forfleskede, forbossede, forfjollede, forjodede, forperket, forhårdede.

\section{Lignende konstruktioner i spansk}

I spansk er præfigerede verbalafledninger generelt meget produktive. Jeg vil i dette afsnit vise at selvom konstruktionernes form og betydningskategorier har klare paralleller i danske præfikskonstruktioner, så adskiller de spanske konstruktioner sig fra hvad jeg i denne artikel har defineret som skematiserende verbalpræfikskonstruktioner i dansk. I visse tilfælde forekommer det spanske præfiks også som præposition i konstruktioner hvor det er uafhængigt af verbaldannelsen som i eksempel (22).

(22) Volaron sobre el campo de batalla. $\rightarrow$ Sobrevolaron el campo de batalla. 'De fløj over kamppladsen’ 'De overfløj kamppladsen'

Denne konstruktionstype er hyppig i dansk og svarer til Åge Hansens (1967) verbale sammensætninger (se afsnit 3). Præfikset er her at betragte som en komponent i et leksikalsk sammensat verbalt prædikat. Hertil kommer at sætningens særlige transitive kernebetydning er transparent og projiceres direkte i det sammensatte verbums leksikalske betydning. Konstruktionstypen har således fundamentale træk der gør den forskellig fra de uadskillelige skematiserende verbalpræfikser i dansk (jf. afsnit 3). I en anden konstruktionstype, som eksemplificeret i (23), har det afledte verbum et aspektuelt præfiks (re- 'ITER') der tilføjer betydningen 'gentagelse' og 'coverage' og derigennem skaber den særlige transitive betydning; sml. afsnit 3.1. 


$$
\begin{aligned}
& \text { Re-corrimos todo el cerro. } \\
& \text { ITER-løb hele bjerget } \\
& \text { 'Vi 'bevandrede" hele bjerget' }
\end{aligned}
$$

Selvom re-konstruktionen i spansk minder meget om den danske $b e$-præfikskonstruktion i dansk (jf. oversættelsen i (23)), kan man konstatere at dens betydning er helt transparent, og re-'s anvendelse er afgrænset til denne specifikke sprogbrug (fordi re- har en præcis og afgrænset aspektuel betydning). Eksempel (24) kan sammenlignes med hvad jeg i afsnit 3.1 har betegnet verbalpræfikskonstruktion med betydningen 'transitiv relation med transfer-/middel-specifikation’ i dansk (jf. oversættelsen).

$$
\begin{array}{llll}
\text { La arena } & \text { em-polv-aba } & \text { los caminos } & \text { y las casas. } \\
\text { Sandet i-støv-datid } & \text { vejene } & \text { og husene } \\
\text { 'Sandet "besmudsede" vejene og husene' (sml. engelsk bedust). }
\end{array}
$$

Basisleksemet er substantivet polvo 'støv/snavs', og betydningen er 'X TRANS Y' + 'specifikation af transfer SUBS '. Konstruktionen er meget hyppig i spansk. Der er en klar parallel til den danske skematiske verbalpræfikskonstruktion hvis man ser på form og betydning, men der er også her en transparent projicering af den spanske sætnings betydning i det afledte verbum $(e m-p o l v o-a r=$ 'i støv-proces'), som mere ligner det leksikalsk sammensatte verbal i dansk (se afsnit 3). Præfikset kan også anvendes selvstændigt som præposition med samme betydning i andre konstruktioner, fx habia polvo $\boldsymbol{e n}(=\mathrm{em})$ las calles $y$ en las casas 'der var støv $\mathbf{i}$ gaderne og husene'. Følgende er eksempler på lignende afledte verber med substantiv som basisleksem: atornillar ' $\mathrm{X}$ forsyner Y med skrue'; encalar 'X dækker Y med kalk'; embaldosar 'X dækker Y med fliser'; empapelar 'X dækker Y med papir'; enjoyar 'X dækker Y med juveler'; enaceitar 'X dækker Y med olie'; enrejar 'X sætter et hegn omkring Y'; ensillar 'X sadler Y; empedrar ' $\mathrm{X}$ dækker $Y$ med sten'; enmarcar 'X sætter ramme om Y; endeudar 'X giver Y gæld'. Eksempel (25) og (26) kan sammenlignes med hvad jeg i afsnit 3.1 har kategoriseret som verbalpræfikskonstruktion med betydningen 'transitiv relation med resultativ betydning' i dansk.

(25) El maquillador em-bell-eció a la chica (con el maquillaje). Sminkøren i-smuk-kede pigen (med makeuppen) 'Sminkøren sminkede pigen smuk' (sml. forskønne, forgude, bemyndige). 

Encarcelaron
al asesino.
i fængsel de anbragte
morderen
'De fængslede morderen'

$\mathrm{I}(25)$ og (26) er betydningen henholdsvis ' $\mathrm{X}$ caused $\mathrm{Y}$ to be $\mathrm{Z}_{\mathrm{ADJ}}$ ' (' $\mathrm{X}$ fik $\mathrm{Y}$ til at være $Z_{\text {ADJ }}$ ') og ' $\mathrm{X}$ caused $\mathrm{Y}$ to move $\mathrm{Z}_{\text {SUBS }}$ ' (' $\mathrm{X}$ fik $\mathrm{Y}$ til at bevæge sig $\left.\mathrm{Z}_{\text {SUBS }}{ }^{\prime}\right)$. De repræsenterer altså to resultative verbalpræfiksvarianter, henholdsvis 'resultativ med tilstandsændring' og 'forårsaget bevægelse' (caused motion). Ligesom den transitive konstruktion med 'transfer'-specifikation (som i (24)) er begge resultative varianter yderst frekvente i spansk. Vi ser også her en klar parallel til de danske verbalpræfikskonstruktioner, både med hensyn til form og betydning, men ligesom i (24) ser vi også at præfikset har en sammenlignelig uafhængig anvendelse som præposition - sml. en belleza 'i smukhed' (25) og en cárcel 'i fængsel' (26) - og en betydningsmæssig transparens projiceret leksikalsk i det sammensatte verbum. Følgende er eksempler på lignende afledte verber med substantiv eller (mere typisk) adjektiv som basisleksem: aclarar 'X gør Y klar' (sml.forklare); atontar 'X

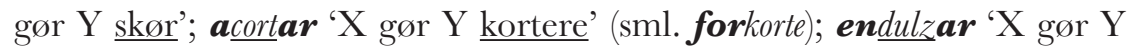

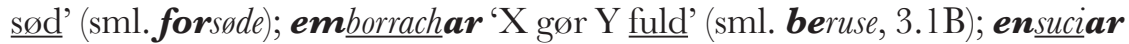
'X gør Y beskidt' (sml. beskide, 3.1A); engordar 'X gør Y tyk'; enfriar 'X gør Y kold'; embrujar 'X gør Y til en heks' (sml. forhekse); embrutecer 'X gør Y brutal' (sml. forrå); empequeñecer 'X gør Y lille' (sml. formindske); empobrecer 'X gør Y fattig'; encarecer ' $\mathrm{X}$ gør Y $\underline{\text { dyr' }}$ ' (sml. fordyre); endurecer ' $\mathrm{X}$ gør Y hård'; enflaquecer ' $\mathrm{X}$ gør $\mathrm{Y}$ tynd'; engrandecer ' $\mathrm{X}$ gør Y stor'; engravecer ' $\mathrm{X}$ gør Y alvorlig' (sml. forvarre); enloquecer ' $\mathrm{X}$

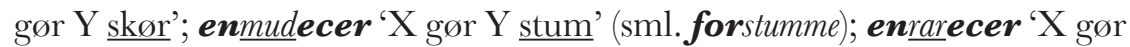
$\mathrm{Y}$ sjælden'; enriquecer 'X gør Y rig' (sml. berige); emblanquecer 'X gør Y

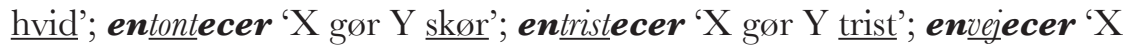
gør Y gammel'; em botellar 'X placerer Y i en flaske'; encaminar 'X bringer Y på vej'; entrampar 'X får Y i en fælde'.

Når vi sammenligner de spanske verbalafledninger med de danske præfikskonstruktioner med be- og for-, er det mest bemærkelsesværdige måske at de produktive spanske konstruktioner, der mht. form og betydning er meget lig de danske, systematisk blokerer for en innovativ, kreativ sprogbrug, som den vi ser i dansk, jf. afsnit 3.1.1. De spanske præfikskonstruktioner implicerer som i dansk produktive morfologiske konstruktioner på ordniveau (Booij 2010), hvor et basisleksem er kerneelementet i afledningen af det sammensatte verbum. Men eftersom der ikke derudover, som i dansk, dannes en præfikskonstruktion med en leksikalsk uafhængig sætningsvalens, 
dvs. en skematisering (konstruktion) af sætningens argumentstruktur (se afsnit 3), er de spanske konstruktioner restriktivt bygget op omkring - og er afhængige af - basisleksemet. Dvs. hvis man eksempelvis vil tale om en landing ved at referere til at en flyvemaskine $(\mathrm{X})$ kommer i kontakt med dansk jord (Y), vil spansktalende vanskeligt kunne gøre det ved at bygge en transitiv konstruktion op omkring rueda 'hjul', fx * $X$ enruedar $Y$ ' $\mathrm{X}$ i hjul Y' som alternativ til den intransitive $X$ aterrizar ' $\mathrm{X}$ til jord $=$ at lande', fordi det valgte basisleksem (rueda 'hjul') er et unaturligt valg i forhold til en verbal opbygning af den intenderede transitive betydning (' $\mathrm{X}$ i kontakt med Y'). Til gengæld kan man godt forestille sig udtryk som $X$ behjuler $\mathcal{Y}$ som alternativ til det intransitive $X$ lander ( $p a ̊ n)$ i dansk, fordi $b e$ - markerer et produktivt transitivt sætningsskema der er relativt uafhængigt af basisleksemet og derfor et potentielt bud på konstruktionen af den intenderede transitive betydning. De spanske præfikskonstruktioner er således ikke, som i dansk, leksikalsk (relativt) uafhængige transitive sætningskonstruktioner der produktivt kan kombineres med innovative basisleksemer der specificerer den transitive relations måde, transfer/middel eller resultat.

\section{Afsluttende bemarkninger}

Jeg har argumenteret for at dansk har produktive transitive verbalpræfikskonstruktioner ( $b e$ - og for-) der potentielt giver mulighed for en særlig innovativ sprogbrug. De kan defineres og klart afgrænses i forhold til andre præfigerede transitive konstruktioner. Spansk har produktive præfikskonstruktioner der både med hensyn til form og betydning ligner de danske konstruktioner. De implicerer imidlertid ikke, som i dansk, et generaliseret, leksikalsk uafhængigt, transitivt valensskema, og man kan derfor ikke observere nydannelser i sprogbrugen af den type vi finder i dansk. I det perspektiv er det ikke kun etymologien, sprogafstamning og de specifikke konstruktioner der binder de germanske be-konstruktioner sammen og afgrænser dem i forhold til sammenlignelige konstruktioner i de romanske sprog; der er formentlig også generelle sprogtypologiske forskelle i spil. Med andre ord opstår sætningskonstruktioner i en historisk kontekst, og de er sprogspecifikke med fællestræk og forskelligheder på tværs af sprog (fx Croft 2001). Hertil kommer imidlertid at den rolle som henholdsvis de produktive mønstre (generaliseret ud fra sprogbrugen) og verbets leksikalske information spiller i sætningsstrukturen, ser ud til at være sprogtypespecifik (jf. Pedersen 2019). 


\section{Om forfatteren}

Johan Pedersen, ph.d., lektor i spansk lingvistik på Københavns Universitet.

\section{Litteratur}

Booij, G. (2010): Construction Morphology. Oxford: Oxford University Press. Croft, W. (2001): Radical construction grammar. Oxford: Oxford University Press. Den Store Danske. Https://denstoredanske.lex.dk.

Durst-Andersen, P. \& M. Herslund. 1996. The Syntax of Danish Verbs: Lexical and Syntactic

Transitivity. I: Content, Expression and Structure. Studies in Danish Functional Grammar. E. Engberg-Pedersen et al. (red.). Amsterdam: John Benjamins, 65-102.

Goldberg, A. (1995): Constructions: A Construction Grammar approach to argument structure. Chicago: The University of Chicago Press.

Hansen, Aa. (1967): Moderne dansk. Det Danske Sprog-og Litteraturselskab. Grafisk forlag.

Haspelmath, M. (2011): On S, A, P, T, and R as comparative concepts for alignment typology. Linguistic Typology 15, 535-567.

Kittilä, S. (2011): Transitivity typology. I: The Oxford handbook of linguistic typology. J.J. Song (red.). Oxford: Oxford University Press, 346-367.

Kulikov, L. (2011): Voice typology. I: The Oxford handbook of linguistic typology. J.J. Song (red.). Oxford: Oxford University Press, 368-398.

Nielsen, J. L. (2018): Rækkefølgen af valensændrende affikser i polysyntetiske sprog. Ny forskning i grammatik, vol. 25, 166-183.

Nordiske sprogproblemer. (1957): Udgivet af Dansk Sprognævn.

Michaelis, L. \& J. Ruppenhofer. (2001): Valence creation and the German applicative: The inherent semantics of linking patterns. Fournal of Semantics 17, 335-395.

ODS. Ordbog over det Danske Sprog.

Pedersen, J. (2019): Verb-based vs. schema-based constructions. A contrastive perspective. Linguistics 57(3), 473-530.

Petré, P. \& H. Guyckens. (2008): Bedusted, yet not beheaded: The role of be-'s constructional properties in its conservation. I: Constructions and Language Change. A. Bergs \& G. Diewald (red.). Berlin: Mouton de Gruyter, 133-169. 